\title{
Analisis potensi dan strategi pariwisata pantai di Kabupaten Buru
}

\author{
Roos Nilawati Marasabessy ${ }^{1^{*}}$, Lutfi Rumkel ${ }^{2}$, Susiati ${ }^{3}$, Andi Masniati ${ }^{4}$, Kurniati \\ Tuasalamony $^{5}$, Nur Fadhilah Amir ${ }^{6}$, Risman lye ${ }^{7}$, Rahma Satya Masna Hatuwe ${ }^{8}$ \\ 1-8 Fakultas Sastra, Universitas Iqra Buru, Indonesia \\ "Korespondensi: sumiatiukitoraja@gmail.com
}

\begin{tabular}{|c|c|}
\hline Info Artikel & \multirow{9}{*}{ 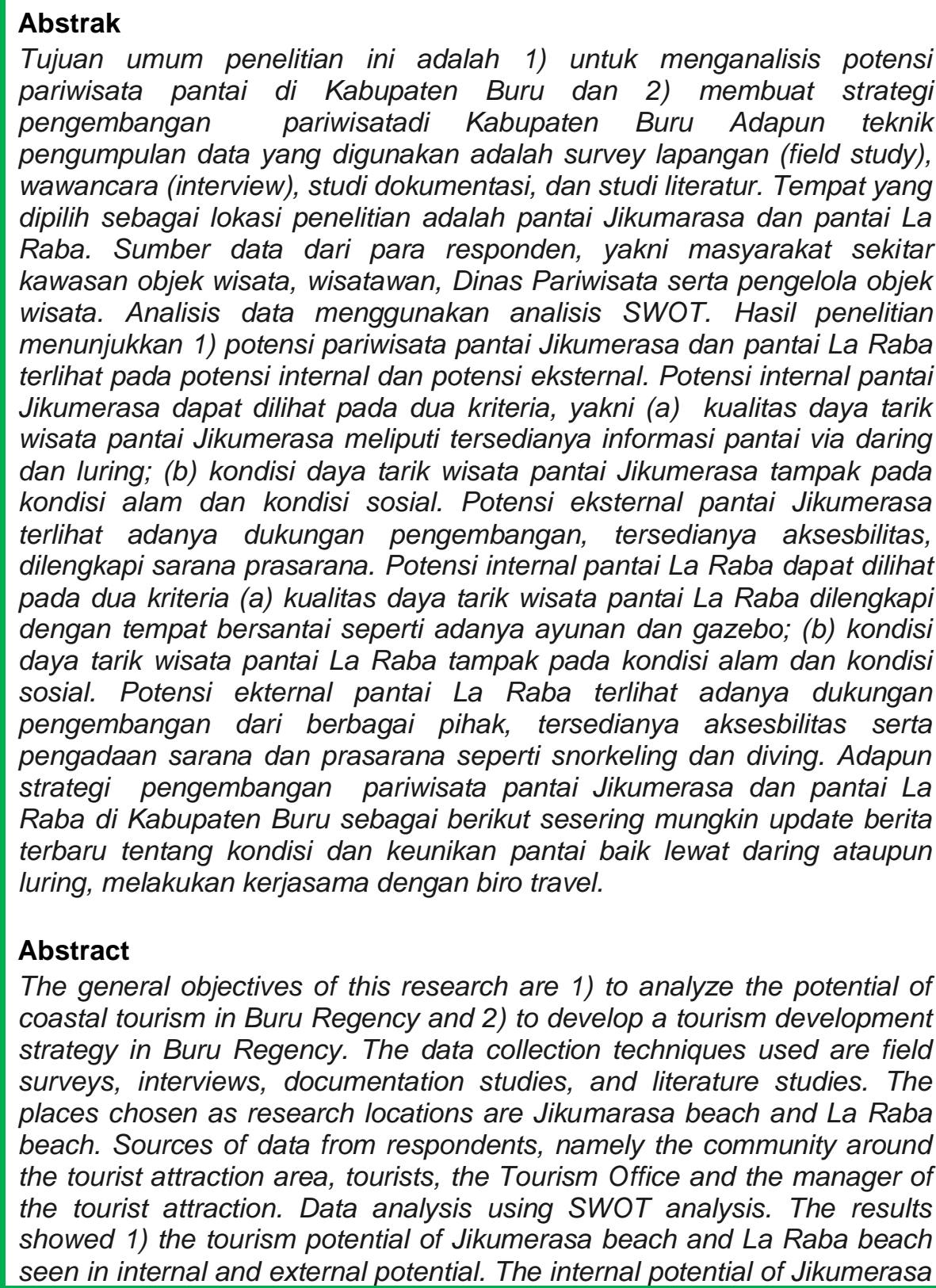 } \\
\hline & \\
\hline & \\
\hline & \\
\hline $\begin{array}{r}\text { Potensi, } \\
\text { Pantai, Ji } \\
\text { La F } \\
\text { Kabupa }\end{array}$ & \\
\hline (c) & \\
\hline & \\
\hline & \\
\hline & \\
\hline
\end{tabular}




\begin{abstract}
beach can be seen in two criteria, namely (a) the quality of Jikumerasa beach tourism attraction including the availability of beach information via online and offline; (b) condition of Jikumerasa beach tourism attraction is seen in natural conditions and social conditions. The external potential of the Jikumerasa beach can be seen from the development support, the availability of accessibility, and facilities and infrastructure. The internal potential of La Raba beach can be seen in two criteria (a) the quality of the La Raba beach tourist attraction, equipped with a place to relax such as a swing and a gazebo; (b) the condition of La Raba beach tourism attraction is seen in natural conditions and social conditions. The external potential of La Raba beach can be seen from the development support from various parties, the availability of accessibility and the provision of facilities and infrastructure such as snorkeling and diving. The strategy for developing Jikumerasa beach and La Raba beach tourism in Buru Regency is as follows as often as possible to update the latest news about the conditions and uniqueness of the beach both online and offline, in collaboration with travel agencies.
\end{abstract}

\title{
1. Pendahuluan
}

Eksistensi pariwisata di Kabupaten Buru memiliki peranan yang utama dalam kepariwisataan di Maluku. Kepariwisataan tersebut ikut andil dalam pembangunan wilayah di Kabupaten Buru. Kabupaten Buru mempunyai potensi pariwisata yang beanekaragam, seperti aset peninggalan sejarah, keberanekaragaman budaya, aneka kuliner, dan beragam potensi wisata lainnya. (Yulianto \& Kumalaningrum, 2020) menyatakan bahwa untuk memajukan suatu daerah menjadi daerah wisata maka dibutuhkan peran aktif pemerintah serta pihak terkait dalam menumbuhkan simpati dan kesadaran para masyarakat tentang pentingnya melestarikan lingkungan alam serta budaya sebagai objek potensial dalam pengembangan pariwisata yang secara tidak langsung hal tersebut mendukung perekenomian dan pembangunan nasional.

Kabupaten Buru terdiri berbagai tempat wisata khususnya wisata pantai. Wisata pantai di Kabupaten Buru tersebar luas di setiap daerah Namun, untuk memperoleh informasi terkait lokasi atau tempat wisata pantai tersebut terkendala karena kurang dan sukarnya media publikasi. Pemerintah Daerah untuk melaksanakan penataan terhadap tempat wisata yang berdaya tarik atau memiliki potensi tempat wi sata, dapat dikembangkan melalui perancangan yang matang, salah satunya dengan menelaah serta mengkaji potensi-potensi yang dimiliki oleh objek wisata tersebut. Sehingga nantinya menjadi salah satu unsur pengembangan pariwisata di Kabupaten Buru serta mampu memberikan peluang terhadap peningkatan penghasilan masyarakat dan penyerapan sumber daya manusia, baik langsung maupun tidak langsung. Seperti yang ditegaskan oleh (Prayudi, 2020) bahwa sektor pariwisata diproyeksikan menjadi penghasil devisa paling besar serta salah satu kunci pengembangan pembangunan negara dan meningkatkan kesejahteraan masyarakat. Pariwisata berperan sebagai faktor pendapatan ekspor, menciptakan lapangan kerja, pengembangan infrastruktur dan peluang usaha.

Secara tegas, terdapat (Peraturan Pemerintah Republik Indonesia, 2011) tentang Rencana Induk Pembangunan Kepariwisataan Nasional yang berisi bahwa kepariwisataan adalah keseluruhan kegiatan yang terkait dengan pariwisata dan bersifat multidimensi serta multidisiplin yang muncul sebagai wujud kebutuhan setiap orang dan negara serta interaksi antara wisatawan dan masyarakat 
setempat, sesama wisatawan, Pemerintah, Pemerintah Daerah dan pengusaha. Pembangunan adalah suatu proses perubahan ke arah yang lebih baik yang di dalamnya meliputi upaya-upaya perencanaan, implementasi, dan pengendalian dalam rangka penciptaan nilai tambah sesuai yang dikehendaki (Febriandhika \& Kurniawan, 2020).

Ketika pariwisata memasuki era kenormalan baru segala sektor termasuk sektor pariwisata ditantang untuk bangkit dan beradaptasi dengan kondisi covid19. Perubahan pandangan sementara terjadi dan beberapa peraturan baru telah diberlakukan dan diterapkan dalam menyambut situasi kenormalan baru pada industri pariwisata seperti setiap pengunjung wajib menggunakan masker dan harus jaga jarak serta disetiap sudut pantai atau area pantai disediakan tempat cuci tangan dan handsanitizer. Kondisi dan ketetapan ini terlihat pula di setiap pantai di Kabupaten Buru termasuk pantai Jikumerasa dan pantai La Raba.

Wisata pantai Jikumerasa dan pantai La Raba pada era kenormalan baru ini banyak digandrungi oleh para wisatawan lokal. Wisatawan lokal cenderung memilih untuk melancong ke pantai-pantai yang ada di sekitaran pulau Buru.

Potensi pariwisata pantai terlihat di beberapa daerah di Kabupaten Buru, diantaranya Desa Jikumarasa, Desa Nametek, dan masih banyak lagi. Terdapat sejumlah pariwisata yang sekarang semakin maju dan berkembang, tetapi sebagian besar masih menginginkan suport serta perhatian lebih dari Pemerintah. Hal tersebut perlu diperhatikan karena diharapkan masyarakat bisa menjadi pengelola sekaligus penanggungjawab daerah wisata tersebut. Terbatasnya infrastruktur fisik dan manajemen pengelolaan menjadi salah satu masalah pada beberapa tempat wisata di Kabuaten Buru sehingga kondisi ini berimplikasi pada daya Tarik wisatawan yang masih rendah.

Hal menjadi dasar pertimbangan sehingga analisis potensi dan strategi pariwisata pantai di Kabupaten Buru khususnya pantai Jikumarasa dan pantai La Raba menjadi objek penelitian, yaitu 1) belum maksimalnya perhatian Pemerintah Daerah dalam memporomosikan dua pantai tersebut; 2) masih lemahnya perhatian masyarakat dan pemerintah dalam menangani keindahan, kebersihan dua pantai tersebut.

Berdasarkan penjelasan di atas, tujuan penelitian ini adalah untuk menganalisis potensi pariwisata pantai di Kabupaten Buru dan membuat strategi pengembangan pariwisata di Kabupaten Buru.

\section{Landasan Teori}

\subsection{Pariwisata}

Suwantoro dalam (Kurniawan, 2015), hakikat berpariwissata adalah suatu rangkaian tindakan bepergian sementara oleh seseorang ke suatu tempat. (Yoeti, Pemasaran Pariwisata, 2013), pariwisata adalah salah satu kegiatan manusia yang dilakukan dengan sadar serta memperoleh pelayanan secara bergantian di antara orang-orang dalam suatu negara itu sendiri atau di luar negeri.

Spilane dalam (Wahid, 2015) mengungkapkan bahwa pariwisata merupakan perjalanan dari satu tempat ke tempat lain yang sifatnya sementara, dilakukan oleh seseorang atau kelompok sebagai upaya ingin mendapatkan balance atau 
keserasian serta rasa bahagia dengan lingkungan hidup dalam dimensi alam, sosial, budaya, dan ilmu pengetahuan.

\subsection{Komponen Pariwisata}

Komponen pariwisata menurut Sugianto dan Sulastriningrum dalam (Gunardi, 2010), meliputi:

a. Objek dan daya tarik wisata

Objek dan daya tarik wisata bisa meliputi panorama alam, anekaragam budaya, atau tata hidup sosial masyarakat yang mempunyai pesona unik (daya tarik) untuk dikunjungi dan menjadi sasaran bagi wisatawan.

b. Sarana dan fasilitas, meliput:

1) Akomodasi

2) Restoran

3) Biro perjalanan

4) Transportasi atau jasa angkutan

5) Tempat penukaran uang

6) Atraksi wisata

7) Cinderamata

8) Prasarana pariwisata

\subsection{Potensi}

Potensi merupakan kekuatan yang memiliki kemungkinan untuk dikembangkan, kekuatan, kesanggupan, serta daya. Sedangkan, pariwisata atau tourism adalah suatu pekerjaan berekreasi atau hiburan. Potensi wisata merupakan berbagai hal yang dipunyai oleh daerah tujuan wisata dan memiliki daya tarik sehingga banyak orang ingin berkunjung ke tempat tersebut (Mariotti dalam (Yoeti, Perencanaan dan Pengembangan Pariwisata, 2008). Sedangkan, pengertian potensi wisata menurut Sukardi (1998:67), potensi wisata merupakan berbagai hal yang dipunyai oleh suatu daerah seperti daya tarik wisata yang berdaya guna dalam pengembangan industri pariwisata di daerah tersebut.

Sementara itu, Sujali dalam (Ridwan, 2012) menyatakan bahwa potensi wisata adalah suatu kemampuan pada suatu wilayah yang mungkin bisa digunakan untuk pembangunan, seperti alam, manusia serta hasil kreatifitas manusia sendiri.

Ada dua klasifikasi potensi pariwisata yang dapat dijadikan rujukan dalam penelitian ini.

a. Potensi Internal

1) Kualitas daya tarik wisata

2) Kondisi daya Tarik wisata

b. Potensi Eksternal

1) Dukungan pengembangan 
2) Aksebilitas

3) Fasilitas penunjang

4) Fasilitas pelengkap

\subsection{Anaisis SWOT}

Analisis SWOT ialah suatu analisis yang mengidentifikasi segala macam faktor dalam merumuskan strategi suatu organisasi. Analisis ini dilandaskan pada logika yang bisa memaksimalkan kekuatan (strengts) dan (opportunities). Namun, secara bersamaan dapat meminimalkan kelemahan (weakness) dan ancaman (threat). Analisa ini menempatkan kondisi sebagai faktor yang dijadikan masukan serta perbaikan. Kemudian berbagai masukan itu dipilah ke dalam tiap kelompok sesuai kontribusinya masing-masing (Rangkuti, 2013).

\section{a. Kekuatan (Strengths)}

Strenght (S) adalah kondisi yang mendeskripsikan kekuatan dari suatu organisasi atau perusahaan pada saat ini. Hal yang mesti dilakukan dalam menggunakan analisis ini ialah tiap perusahaan atau organisasi harus menilai kekuatan dan kelemahan yang dipunyai kemudian diperbandingkan dengan para pesaing-pesaingnya. Contoh:

1) Potensi pariwisata alam yang cukup berkembang dapat meningkatkan perekonomian;

2) Letak strategis dan mudah dijangkau;

3) Memiliki beragam wahana (perahu, kereta wisata, dan lain-lain);

4) Potensi lahan di kawasan budidaya dapat dijadikan lokasi pembangunan

\section{b. Kelemahan (Weakness)}

Kelemahan (Weaknesses) dilambangkan dengan $W$, yaitu kondisi yang mendeskripsikan kelemahan dari suatu organisasi atau perusahaan pada saat ini. Weakness adalah jalan dalam menganalisis kelemahan yang terdapat pada perusahaan ataupun organisasi. Weakness tersebut bisa menjadi hambatan yang serius terhadap majunya suatu perusahaan atau organisasi. Contoh:

1) Kurang digiatkannya perawatan pada wahana dan fasilitas pendukung

2) Pengeloaan kebersihan di pesisir pantai kurang

3) PKL tidak tertata dengan baik sehingga para PKL berjualan di area jalan

4) Kebersihan lingkungan kawasan pantai belum terorganisir dengan baik seperti penyediaan tempat sampah di beberapa titik strategis.

\section{c. Peluang (Opportunity)}

Peluang atau opportunity $(\mathrm{O})$, ialah kondisi yang mendeskripsikan adanya peluang pada sisi eksternal perusahaan atau organisasi. Pendeskripsian tersebut bisa memberikan peluang atau ruang gerak terhadap perkembangan suatu organisasi atau perusahaan di masa depan. Opportunity ialah analisis yang dipergunakan untuk mendeteksi ruang gerak ataupun terobosan yang mungkin 
suatu perusahaan ataupun organisasi bisa berkembang. Baik di masa sekarang atau di masa mendatang. Contoh:

1) Daya tarik wisata pantai yang potensial untuk dikembangkan

2) Daya tarik wisata pantai yang banyak diminati masyarakat

3) Lokasi tidak jauh dari pusat kota dan bernilai komersial tinggi sehingga nilai investasi tinggi

4) Ruang terbuka (open space) kawasan pantai masih luas

\section{d. Ancaman (Threat)}

Ancaman atau threat $(\mathrm{T})$, adalah suatu kondisi mendeskripsikan adanya ancaman dari suatu perusahaan atau oraganisasi dalam menjalankan suatu usaha. Threat ialah jalan dalam menganalisis tantangan/hambatan serta ancaman yang mesti tanggulangi oleh suatu perusahaan ataupun organisasi dalam menghadapi segala macam faktor lingkungan yang merugikan. Di mana threat tersebut bisa menjadikan terjadinya kemunduran pada perusahaan. Jika hal itu tidak secepatnya diatasi, maka threat itu akan menjadi penghalang terhadap usaha yang dijalankan.

1) Ketersediaan kendaran umum yang tidak regular

2) Pengunjung paling banyak pada hari libur

3) Perhatian pemerintah dan swasta dalam pengelolaan belum maksimal

\section{Metode}

\subsection{Jenis Penelitian}

Metode yang digunakan dalam penelitian ini adalah metode deskriptif kualitatif. Metode deskriptif kualitatif diharapkan dapat menghasilkan uraian yang mendalam terhadap objek yang diamati dari suatu individu, kelompok, masyarakat atau organisasi tertentu yang dikaji dari sudut pandang yang utuh, komprehensif, dan holistik (Bogdan dan Taylor dalam (Moleong, 2007).

\subsection{Data dan Sumber Data}

Tempat yang dipilih sebagai lokasi penelitian adalah pantai Jikumarasa dan pantai La Raba. Sumber data dari para responden, yakni masyarakat sekitar kawasan objek wisata, wisatawan, Dinas Pariwisata serta pengelola objek wisata. Hasil dari wawancara tersebut digunakan sebagai salah satu dasar penilaian untuk mengevaluasi dan mengkaji potensi-potensi pariwisata pantai dan penemuan strategi yang perlu dikembangkan oleh pihak-pihak terkait terhadap pengembangan potensi wisata pantai di Kabupaten Buru.

Adapun pariwisata pantai di Kabupaten Buru yang dianggap memiliki potensi terhadap pengembangan Pariwisata di Kabupaten Buru secara keseluruhan, yaitu pantai Jikumarasa dan pantai La Raba.

\subsection{Metode dan Teknik Pengumpulan Data}

Adapun teknik pengumpulan data yang digunakan dalam penelitian ini adalah survey lapangan (field study), wawancara (interview), studi dokumentasi, dan studi literatur. 


\subsection{Penganalisisan Data}

Penelitian ini adalah peneltian kualitatif. Penelitian kualitatif menyajiikan hasil penelitiannya secara deskriptif kualitatif yang akan melihat dan mengidentifikasi potensi dan strategi melalui wawancara secara mendalam dengan para narasumber. Selanjutnya, data-data yang diperoleh tersebut dikumpulkan, disusun, dan diklasifikasikan, kemudian dianalisis menggunakan analisi SWOT. Analisis SWOT merupakan cara atau tindakan yang diambil dengan berdasar pada prinsipprinsip mengembangkan kekuatan (strengths), meminimalkan kelemahan (weakness), menangkap kesempatan/peluang (opportunity), dan menghilangkan ancaman (threat).

\section{Pembahasan}

\subsection{Potensi Pariwisata Pantai di Kabupaten Buru}

\subsubsection{Potensi Internal dan Eksternal Pariwisata Pantai Jikumerasa}

Adapun potensi pariwisata pantai Jikumerasa dapat diidentifikasi melalui potensi internal dan potensi eksternal. Berikut penjelasannya.

\section{a. Potensi Internal Pariwisata Pantai Jikumerasa}

Pantai Jikumerasa merupakan salah satu pantai yang menjadi icon pariwisata Kabupaten Buru. Ada dua potensi internal yang mendukung pantai Jikumerasa, yakni kualitas daya tarik wisata dan kondisi daya tarik wisata.

\section{b. Kualitas Daya Tarik Wisata Pantai Jikumerasa}

Kualitas daya tarik wisata di Pantai Jikumerasa meliputi

a) Informasi yang lengkap baik melalui website atau brosur tentang kawasan wisata pantai Jikumerasa menjadi salah satu daya tarik para wisatawan

b) Para wisatawan tertarik datang berkunjung ke Pantai Jikumerasa karena kondisi jalan raya yang baik.

c) Pantai Jikumerasa memiliki keunikan tersendiri terdapat beberapa wahana bersantai, seperti ayunan dan gazebo

d) Posisi pantai Jikumerasa sangat strategis dan dikelilingi oleh pepohonan mangrove (bakau), pohon kelapa, dan pohon cemara udang.

e) Menyajikan keindahan laut dan pasir yang putih serta terdapat spot pantai air asin

\section{c. Kondisi Daya Tarik Wisata Pantai Jikumerasa}

Kondisi daya tarik wisata pantai Jikumerasa meliputi

1) Kondisi Alam

Posisi pantai Jikumerasa sangat strategis, yakni di peisir laut yang dipenuhi dengan pepohonan seperti pohon kelapa, pohon ketapang, pohon cemara udang, dan pohon bakau. Keindahan laut yang biru dan pasir yang putih menambah nilai pada pantai Jikumerasa. Hal ini, tidak terlapas dari pengelolaannya oleh pihak pengelola. Pantai Jikumerasa merupakan salah satu icon pariwisata yang dipercaya oleh pemerintah dapat mendatangkan devisa. Banyak pengunjung baik itu dari wisatawan lokal maupun luar daerah pulau Buru. 
Kekayaan yang dimiliki oleh pantai Jikumerasa bukan hanya pasir dan lautnya yang putih, tetapi terdapat pula danau air asin. Danau terisi ketika air laut dalam keadaan pasang dan mongering saat air laut surut. Danau air asin tersebut menambah keindahan pantai Jikumerasa dengan warna turquoise dan dipenuhi dengan tumbuhan alga hijau dan bulu babi. Dengan keindahan fisiknya ini pantai Jikumerasa masuk pada nominasi Anugerah Pesona Indonesia (API) II 2017 dalam kategori Obyek Wisata Bersih Terpopuler.

Namun, dari beberapa potensi fisik yang dimiliki oleh pantai Jikumerasa terdapat pula beberapa hambatan seperti keadaan kebersihan pantai yang kurang terawat, sehingga membuat sisi keindahan pantai menurun.

\section{2) Kondisi Sosial}

Saat ini pantai Jikumerasa dikelola oleh pemerintah Kabupaten Buru bersama masyarakat. Masyarakat sering datang menjajakan jualan kepada para pengunjung. Di pantai Jikumerasa telah disediakan rumah makan (warung) yang dikelola oleh sekelompok masyarakat dengan izin dari pemerintah setempat. Pemberdayaan pelaku usaha ini oleh pemerintah setempat bertujuan agar masyarakat dapat mendapatkan penghasilan guna memenuhi kebutuhan keluarga.

Menurut hasil wawancara dari para penjual di pantai Jikumerasa, setiap hari omset yang dihasilkan sekitar kurang lebih Rp. 600.000 sampai 1.000.000. Hal ini, dapat disimpulkan bahwa pengunjung di pantai Jikumerasa terbilang banyak. Para pengunjung datang dari berbagai daerah baik itu dari wisatawan lokal maupun wisatawan luar daerah.

\section{d. Potensi Eksternal Pariwisata Pantai Jikumerasa}

1) Dukungan pengembangan

Dukungan pengembangan pantai Jikumerasa terdiri dari dukungan dari pemerintah pusat dan pemerintah daerah Kabupaten Buru dan masyarakat. Dukungan dari pemerintah pusat khususnya Kementerian Pariwisata Republik Indonesia terlihat ketika pantai Jikumerasa dimasukkan pada nominasi Anugerah Pesona Indonesia (API) II 2017 dalam kategori Obyek Wisata Bersih Terpopuler. Selain itu, dukungan dari Pemerintah Daerah terlihat adanya pembanguan dan pengadaan dive centre yang berfungsi untuk memberikan pelayanan kepada para wisatawan atau pengunjung jika ingin melakukan snorkeling dan diving. Tampak pula dukungan dari masyarakat di Desa Jikumerasa yang selalu membersihkan area-area pantai. Selain itu, mereka pula memanfaatkan area-area di sekitaran pantai untuk membangun rumah makan (warung).

\section{2) Aksebilitas}

Pantai Jikumerasa terletak di Desa Jikumerasa, Kecamatan Lilialy, Kabupaten Buru. Jarak pantai Jukumerasa dari Ibukota Kabupaten, yakni 10 km. Ada beberapa pilihan alat transportasi yang dapat digunakana untuk akses menuju pantai Jikumerasa antara lain

(a) Menggunakan Mobil Penumpang (pete-pete)

Pantai Jikumerasa dapat diakses dengan mudah menggunakan alat transportasi mobil penumpang (pete-pete). Mobil penumpang tersebut dapat diperoleh pada beberapa titik di kota Namlea seperti terminalnya yang berada di 
pasar Namlea dan dapat menunggu di tepi jalan raya. Jika wisatawan ingin berkunjung ke pantai Jikumerasa maka dapat naik ojek ke terminal di Pasar Namlea. Adapun biayanya sekitar Rp. 20.000 per orang.

\section{(b) Menggunakan Bus}

Alat transportasi bus juga menjadi salah satu alternatif para wisatawan untuk berkunjung ke Pantai Jikumerasa. Namun, untuk menggunakan alat transportasi ini harus melalui permintaan kepada Dinas Perhubungan Kabupaten Buru dan para wisatawan harus dalam jumlah besar atau banyak.

(c)Menggunakan kendaraan pribadi

Rute kendaraan pribadi menuju pantai Jikumerasa menjadi pilihan favorit oleh para wisatawan khususnya wisatawan lokal.

(d) Menggunakan mobil sedan

Transportasi mobil sedan merupakan salah satu alternatif pilihan transportasi untuk keluarga yang ingin berwisata di Pantai Jikumerasa. Mobil sedan biasanya di sewakan kepada para wisatawan yang ingin berkunjung di berbagai destinasi yang ada di Kabupaten Buru. Harga sewa mobil sedan tersebut seharga Rp. 500.000 pulang pergi.

3) Sarana dan Prasarana

Penyediaan sarana di pantai Jikumerasa sampai saat ini khususnya penyediaan sarana warung makan bagi masyarakat yang ingin membuka usaha di pantai Jikumerasa. Beberapa fasilitas seperti warung makan yang tertata rapi tersebut dilengkapi dengan kamar mandi, gazebo (tempat bersantai para pengunjung) melepas penat saat ingin berenang atau sehabis berenang.

Selain itu, di pantai Jikumerasa terdapat pula ayunan yang berfungsi untuk tempat istrahat dan latar dalam mengambil gambar atau foto para pengunjung. Terlihat dari luar gerbang pantai Jikumerasa terdapat tulisan "Pantai Jikumerasa" berukuran besar di tembok pagar luar pantai. Berbagai ornamen papan yang dipenuhi dengan tulisan-tulisan yang dapat menarik perhatian dan membuat pengunjung penasaran. Pemerintah juga membangun dive centre yang berfungsi untuk memberikan pelayanan kepada para wisatawan atau pengunjung jika ingin melakukan snorkeling dan diving.

\subsubsection{Potensi Internal dan Eksternal Pariwisata Pantai La Raba}

Adapun potensi pariwisata pantai La Raba dapat diidentifikasi melalui potensi internal dan potensi eksternal. Berikut penjelasannya.

\section{a. Potensi Internal Pariwisata Pantai La Raba}

Pantai La Raba merupakan salah satu pantai yang menyuguhkan panorama laut di dan pasir di Kabupaten Buru. Ada dua potensi internal yang mendukung pantai La Raba, yakni kualitas daya tarik wisata dan kondisi daya tarik wisata.

1) Kualitas Daya Tarik Wisata Pantai La Raba

Kualitas daya tarik wisata di Pantai La Raba meliputi 
a) Informasi lengkap tentang pantai La Raba tersedia dalam berbagai media sosial hasil dari dokumentasi para pengunjung seperti via YouTube, instragram, facebook, dan lain sebagainya.

b) Para wisatawan tertarik datang berkunjung ke Pantai La Raba karena tempatnya strategis dan dekat dengan perkampungan, letak pantai berada di pesisir laut kota Namlea.

c) Pantai La Raba memiliki keunikan tersendiri terdapat beberapa wahana bersantai, seperti ayunan, gazebo (tempat beristrahat) dan jembatan panjang yang menjulur ke laut.

d) Memiliki warna pasir yang kecoklatan dan laut yang berwarna jernih.

e) Posisi pantai La Raba sangat strategis dan dikelilingi oleh pepohonan mangrove (bakau), pohon kelapa, dan pohon cemara udang.

f) Memanjakan mata dengan lalu lalangnya perahu para nelayan

2) Kondisi Daya Tarik Wisata Pantai La Raba

a) Kondisi Alam

Kondisi alam pantai La Raba menyajikan pemangangan yang indah. Meskipun lokasinya kurang luas tetapi kejernihan laut membuat pantai La Raba terlihat eksotik. Pantai La Raba dikelola oleh seseorang atau bersifat pribadi.

Letak pantai berada di pesisir kota Namlea khususnya di Desa Nametek. Pohon kelapa hibrida, pohon bakau, dan pohon cemara udang terlihat pula tumbuh di Pantai La Raba sehingga udara sangat sejuk dan menjadikan pantai menjadi teduh.

b) Kondisi Sosial

Para pengunjung atau wisatawan di Pantai La Raba sangat banyak pada akhir pekan dan pada hari-hari lainnya. Dengan letak pantai yang dekat dengan pemukiman warga kota Namlea menjadikan pantai La Raba sebagai tempat melepas penat pada sore hari oleh sekelompok orang.

Pantai La Raba mempunyai satu rumah makan dan toilet. Hal ini, kurang maksimal dan efektif jika dibandingkan dengan jumlah wisatawan yang cukup banyak. Masyarakat jika ingin berjualan di sekitaran pantai La Raba harus melalui izin dari pengelola pantai. Jika pengunjung ingin memasuki Pantai La Raba harus membayar sekitar Rp. 2.000 per orang dan Rp. 5.000 jika ada kendaraan.

\section{b. Potensi Eksternal Pariwisata Pantai La Raba}

1) Dukungan pengembangan

Meskipun pantai La Raba dikelola oleh seseorang tetapi dukungan pemerintah selalu ada. Hal ini dilakukan agar kemajuan sektor pariwisata di Kabupaten Buru merata. Pengelola pantai La Raba masih dalam tahap reklamasi tetapi sedikit demi sedikit pengembangan pantai terlihat dengan tersedianya dive centre yang berfungsi untuk memberikan pelayanan kepada para wisatawan atau pengunjung jika ingin melakukan snorkeling dan diving. Selain itu, pihak pemerintah terkait sering menggiring para masyarakat untuk membersihkan lingkungan pantai La Raba. 
2) Aksebilitas

Pantai La Raba terletak di Desa Nametek, Kabupaten Buru. Jarak pantai La Raba dari lbukota Kabupaten, yakni $5 \mathrm{~km}$. Ada beberapa pilihan alat transportasi yang dapat digunakan untuk akses menuju pantai La Raba antara lain

a) Menggunakan Bus

Alat transportasi bus juga menjadi salah satu alternatif para wisatawan untuk berkunjung ke Pantai La Raba. Namun, untuk menggunakan alat transportasi ini harus melalui permintaan kepada Dinas Perhubungan Kabupaten Buru dan para wisatawan harus dalam jumlah besar atau banyak.

b) Menggunakan kendaraan pribadi

Rute kendaraan pribadi menuju pantai La Raba menjadi pilihan favorit oleh para wisatawan khususnya wisatawan lokal.

c) Menggunakan mobil sedan

Transportasi mobil sedan merupakan salah satu alternatif pilihan transportasi untuk keluarga yang ingin berwisata di Pantai La Raba. Mobil sedan biasanya di sewakan kepada para wisatawan yang ingin berkunjung di berbagai destinasi yang ada di Kabupaten Buru. Harga sewa mobil sedan tersebut seharga Rp. 250.000 pulang pergi.

3) Sarana dan Prasarana

Beberapa penyediaan sarana di pantai La Raba yang tampak saat ini disesuaikan dengan kondisi kenormalan baru (New Normal). Hal ini dilakukan karena faktor pandemik covid-19. Sebagai contoh adalah pengadaan tempat cuci tangan, sabun, dan handsanitizer di setiap sudut gazebo, adanya warung yang menyediakan berbagai makanan khas Pulau Buru. Selain itu, adapula kamar mandi serta ayunan.

Fasilitas di pantai La Raba didesain dengan berbagai varian warna. Sehingga dapat disimpulkan destinasi pantai di Kabupaten Buru dari segi desain warna sama, yakni menggunakan pewarnaan yang warna warni. Enam meter ke dalam dari pintu masuk terdapat tulisan besar yang tertulis "Telaba Beach". Sebenarnya nama baru dari pantai La Raba adalah Telaga Beach tetapi nama pantai La Raba lebih dikenal dan dipakai oleh masyarakat luas Pulau Buru.

\subsection{Strategi Pengembangan Pariwisata di Kabupaten Buru}

Dalam rangka pengembangan wisata pantai Jikumerasa dan pantai La Raba di Kabupaten Buru terdapat beberapa fakta yang terkait dengan potensi (dilihat dari peluang, kekuatan, kelemahan, dan ancaman) kedua pantai tersebut. Adapun uaraian beberapa fakta yang dimaksud adalah sebagai berikut.

a. Potensi pariwisata alam yang cukup berkembang dari segi perekonomian

b. Letak kedua pantai (pantai Jikumerasa dan pantai La Raba) sangat strategis dan mudah dijangkau.

c. Terdapat sarana yang dapat dijadikan sebagai wahana.

d. PKL tertata rapi tetapi masih kurang memadai

e. Kurangnya perawatan terhadap wahana dan fasilitas pendukung 
f. Pengelolaan kebersihan di sekitar lingkungan pantai kurang maksimal

g. Adanya penyediaan tempat sampah di beberapa titik

h. Ruang terbuka (open space) di kawasan pantai masih luas

i. Ketersediaan kendaraan umum tidak regular

j. Penguasaan Teknologi Tepat Guna (TTG) untuk Pengolahan Produk

k. Adanya perhatian pemerintah dan swasta dalam pengelolaan belum maksimal.

\subsubsection{Analisis SWOT Potensi dan Strategi Pantai Jikumerasa}

\section{Kekuatan (Strengths)}

a. Pantai Jikumerasa terletak tidak jauh, yakni $10 \mathrm{~km}$ dari pusat kota Namlea. Hal ini menjadikan pantai Jikumerasa tempat rekreasi wisatawan lokal dan wisatawan yang berasal dari luar daerah.

b. Lokasi pantai yang strategis berada dekat dengan bibir jalan raya dan di samping kiri dan kanan pantai terdapat pula pantai lain, yakni pantai Ako dan pantai Boikolet.

c. Pantai yang menyajikan hamparan pasir putih yang panjang dan bersih

d. Terdapat wahana ayunan yang berfungsi umtuk tempat mengambil gambar oleh para pengunjung.

e. Terdapat jembatan panjang menjulur ke laut

f. Memiliki laut yang jernih

g. Menikmati pemandangan dan kebanyakan dari wisatawan datang memancing.

h. Terdapat sarana diving dan snorkling disediakan oleh Dinas Pariwisata Kabupaten Buru

i. Tersedia warung makan

j. Sudah dalam proses pengembangan dan sudah dipublikasikan

Kelemahan (Weakness)

a. Tidak tersedia transportasi regular. Transportasi regular tersedia hanya untuk para wisatawan yang ingin melakukan tour dalam jumlah banyak oleh dinas pariwisata.

b. Para PKL belum sepenuhnya tertib

c. Kebersihan lingkungan sekitar pantai Jikumerasa kurang diterapkan sehingga banyak kotoran plastik yang berserakan

d. Aktivitas dan fasilitas wisata pantai Jikumerasa masih sangat terbatas dan kurang terawat.

e. Tempat sampah yang tidak dikelola dan toilet yang kurang berfungsi

f. Tidak tersedianya air bersih (air tawar) 
g. Kombinasi setiap komponen kurang mampu mempertinggi kualitas obyek.

h. Lahan parkir tidak ada. Kendaraan yang diparkir tidak teratur.

\section{Peluang (Opportunity)}

a. Adanya minat pemerintah Kabupaten Buru dan masyarakat setempat dalam pengembangan pantai

b. Menciptakan lapangan pekerjaan bagi masyarakat di sekitar pantai

c. Ruang terbuka di sekitar pantai masih luas

d. Daya tarik wisata pantai yang potensial untuk dikembangkan

e. Memiliki daya Tarik wisata pantai yang banyak diminati wisatawan.

\section{Ancaman (Threat)}

a. Terdapat pantai lain yang fasilitasnya lebih memadai

b. Obyeknya masih tergolong tunggal

c. Ketersediaan kendaraan umum yang tidak regular

d. Pengunjung terbanyak terlihat pada hari-hari libur

e. Perhatian pemerintah dalam pengelolaan belum maksimal

\subsubsection{Analisis SWOT Potensi dan Strategi Pantai La Raba}

\section{Kekuatan (Strengths)}

a. Lokasi pantai La Raba berada di pesisir kota Namlea

b. Terdapat beberapa tempat beristrahat yang biasa disebut gazebo yang tertata rapi

c. Adanya pihak yang bertugas menjaga kebersihan pantai

d. Terdapat warung makan

e. Tempat sampah tertata rapi di setiap gazebo

f. Terdapat ayunan untuk tempat bersantai para pengunjung

g. Latar fasilitas yang ada di pantai La Raba warna warni

h. Terdapat jembatan yang menjulur ke laut

\section{Kelemahan (Weakness)}

a. Jalan masuk menuju pantai sempit dan rusak

b. Tidak tersedianya klinik kesehatan atau SAR Rescue

c. Tempat warung makan masih kurang

d. Perawatan kebersihan kamar mandi masih kurang 


\section{Peluang (Opportunity)}

a. Pantai La Raba memiliki pemandangan yang indah

b. Pantai La Raba dipercaya dapat menjadi penguatan sektor dalam bidang perikanan, yakni dapat dijadikan tempat pelelangan dan kampong nelayan.

c. Pantai La Raba merupakan pantai yang cenderung baru dan banyak dari wisatawan yang belum mengetahui tentang keberadaan dari pantai La Raba.

d. Penguatan dalam sektor promosi akan berdampak baik bagi keparawisatawan di Pantai La Raba

e. Menciptakan lapangan pekerjaan bagi masyarakat di sekitar pantai.

\section{Ancaman (Threat)}

a. Seperti yang telah kita ketahui banyak sekali pantai-pantai yang berlokasi di pesisir laut Kabupaten Buru dengan karakteristik yang hamper sama menjadikan persaingan sebagai ancaman bagi pantai La Raba

b. Reklamasi pantai yang masih berjalan

c. Lokasi pantai sempit

d. Dikelola oleh pribadi sehingga masyarakat yang akan mendirikan warung makan harus melalui izin dari pengelola pantai.

Berdasarkan penggalian informasi dari para informan diperoleh data, pengamatan, dan fakta. Informasi yang dimaksud dideskripsikan dengan menggunakan analisis SWOT. Dari hasil identifikasi dan pendeskripsian terkait kekuatan, kelemahan, peluang, dan ancaman yang ada di Pantai Jikumerasa dan di Pantai La Raba. Dari proses deskripsi dan identifikasi tersebut dapat ditentukan strategi yang dapat diterapkan untuk kemajuan dan pengembangan pantai Jikumerasa dan pantai La Raba. Adapun strategi yang dimaksud adalah sebagai berikut.

a. Mempromosikan pantai dengan cara membuat dan menyebarkan brosur serta membuat website

b. Membuat dan aktif melakukan up date informasi dalam website

c. Melakukan kerjasama dengan biro travel, lembaga pendidikan, dan investor

d. Menyiapkan sarana dan prasarana fisik untuk menunjang wisata

e. Mengadakan pelatihan budidaya produk lokal kepada para PKL sebagai bentuk pengembangan produk wisata

f. Membuat paket agrowisata yang menekankan pada pengembangan potensi wisata pada sektor perikanan dan alam

\section{Penutup}

Berdasarkan hasil penelitian dalam pembahasan sebelumnya, dapat disimpulkan beberapa hal yang menjadi temuan dalam penelitian ini terkait potensi 
pariwisata pantai di Kabupaten Buru dan strategi pengembangan pariwisata pantai di Kabupaten Buru.

Adapun potensi pariwisata pantai Jikumerasa dan pantai La Raba terlihat pada potensi internal dan potensi ekternal. Potensi internal pantai Jikumerasa dapat dilihat pada dua kriteria, yakni 1) kualitas daya tarik wisata pantai Jikumerasa meliputi tersedianya informasi pantai via daring dan luring, kondisi jalan raya yang baik, pantai yang terbilang unik dan tersedia wahana bersantai, letaknya strategis dan dikelilingi oleh berbagai macam pepohonan yang rindang; 2) kondisi daya tarik wisata pantai Jikumerasa meliputi kondisi alam yang indah terlihat dari pasir putih dan laut jernih; kondisi sosial meliputi pengunjung lokal dan luar daerah sering berkunjung di pantai Jikumersa. Selain itu, masyarakat sekitar pantai ikut berpartisipasi menjajakan dagangan. Potensi ekternal pantai Jikumerasa terlihat adanya dukungan pengembangan dari pemerintah pusat, pemerintah daerah, dan masyarakat; aksesbilitas yang lancar dan aman; telah dilengkapi sarana prasarana.

Potensi internal pantai La Raba dapat dilihat pada dua kriteria 1) kualitas daya tarik wisata pantai La Raba meliputi informasi tentang pantai dapat diperoleh lewat YouTube, instragram, facebook, dan lain sebagainya, tempatnya strategis tidak jauh dari kota, pantai La Raba dilengkapi dengan tempat bersantai seperti adanya ayuunan, gazebo, jembatan panjang yang menjulur ke laut, memiliki pasir yang kecoklatan dan laut yang jernih, dan dikelilingi oleh berbagai macam pohon. 2) kondisi daya tarik wisata pantai La Raba meliputi kondisi alam yang sejuk dan rindang serta pemandangan yang indah. Potensi ekternal pantai La Raba terlihat adanya dukungan dari pemerintah daerah, meskipun pantai La Raba miliki pribadi tetapi pemerintah daerah Kabupaten Buru selalu memberikan dukungan untuk pengembangan pantai La Raba, aksesbilitas sangat lancar dapat dijangkau dengan kendaraan pribadi ataupun mobil sewaan, adanya pengadaan sarana dan prasarana snorkeling dan diving bagi para wisatawan.

Adapun strategi pengembangan pariwisata pantai Jikumerasa dan pantai La Raba di Kabupaten Buru sebagai berikut: sesering mungkin update berita terbaru tentang kondisi dan keunikan pantai baik lewat daring ataupun luring, melakukan kerjasama dengan biro travel, lembaga pendidikan, dan investor, menyiapkan sarana dan prasarana fisik untuk menunjang wisata, engadakan pelatihan budidaya produk lokal kepada para PKL sebagai bentuk pengembangan produk wisata, membuat paket agrowisata yang menekankan pada pengembangan potensi wisata pada sektor perikanan dan alam.

\section{Ucapan Terimakasih}

Ucapan terima kasih penulis ucapkan kepada pengelola Jurnal SANG PENCERAH atas diterimanya artikel ini untuk dipublikasi. Penulis juga mengucapkan terima kasih kepada Kemenristekdikti dan LLDikti Wilayah XII Maluku dan Maluku Utara atas kepercayaannya memberikan dana hibah terhadap penelitian ini. Selanjutnya, ucapan terima kasih penulis ucapkan kepada Ketua Yayasan Muslim Buru, Rektor Universitas Buru, dan LPPM Universitas Iqra Buru atas dukungan sehingga penelitian ini dapat selesai tepat waktu. 


\section{Daftar Pustaka}

Febriandhika, I., \& Kurniawan, T. (2020). Pengembangan Pariwisata Melalui Pemberdayaan Mayarakat Dilihat Dari Perspektif Implementasi Kebijakan. Jurnal Pariwisata Pesona, 5(1), 1-11. doi:10.26905/jpp.v5i1.2793

Gunardi, G. (2010). Identifikasi Potensi Kawasan Wisata Kali Pasir, Kota Tangerang. Jurnal Planesa, 1(1), 28-35.

Kurniawan, W. (2015). Dampak Sosial Ekonomi Pembangunan Pariwisata Umbul Sidomukti Kecamatan Bahdungan Kabupaten Semarang. Laporan Penelitian, 1-20.

Moleong, L. (2007). Metodologi Penelitian Kualitatif. Bandung: Remaja Rosdakarya.

Peraturan Pemerintah Republik Indonesia. (2011). Renstra Induk Pembangunan Kepariwisataan Nasional No 50. Jakarta: Kementerian Pariwisata.

Prayudi, M. A. (2020). Prospek Pengembangan Pariwisata Berbasis Kearifan Lokal Di Kabupaten Kulonprogo. Khasnah IImu-Jurnal Pariwisata Dan Budaya, 11(1), 27-32.

Rangkuti, F. (2013). Analisis SWOT (Edisi Revisi). Jakarta: Gramedia Pustaka Utama.

Ridwan, M. (2012). Perencanaan Pariwisata dan Pengembangan Pariwisata. Medan Polania: PT Sofmedia.

Sukardi, N. (1998). Pengantar Pariwisata. Nusa Dua Bali: STP.

Undang-Undang Republik Indonesia Nomor. (2009). Kepariwisataan. Jakarta: Sekretariat Negara RI.

Wahid, A. (2015). Strategi Pengembangan Wisata Nusa Tenggara Barat Menuju Destinasi Utama Wisata Islami. Skripsi, 1-134.

Yoeti, A. O. (2008). Perencanaan dan Pengembangan Pariwisata. Jakarta: Pradaya Paramita.

Yoeti, A. O. (2013). Pemasaran Pariwisata. Bandung: CV Angkasa.

Yulianto, A., \& Kumalaningrum, A. (2020). Potensi Pengembangan Destinasi Wisata Umbul Pluneng Di Kabupaten Klaten Jawa Tengah. Khasanah IImuJurnal Pariwisata Dan Budaya, 11(1), 50-60. 